Imágenes en Medicina Intensiva

\title{
Papel de la ecocardiografía en el shock cardiogénico
}

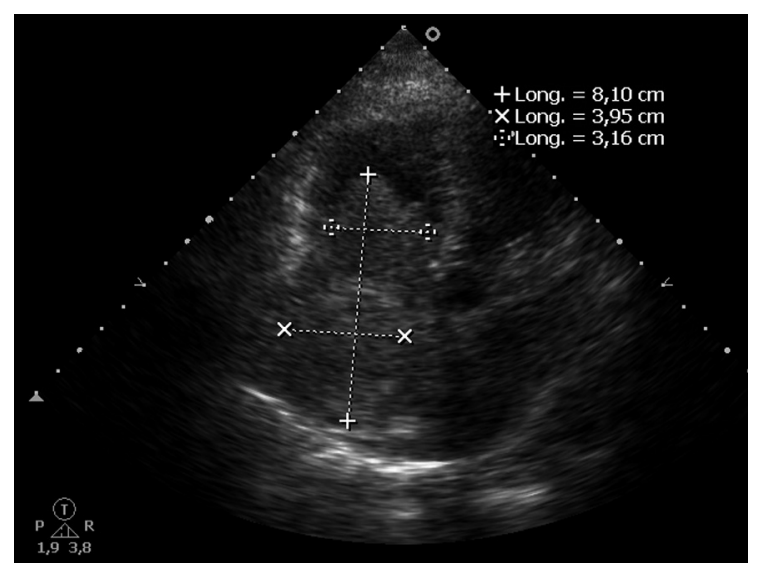

Figura 1 .

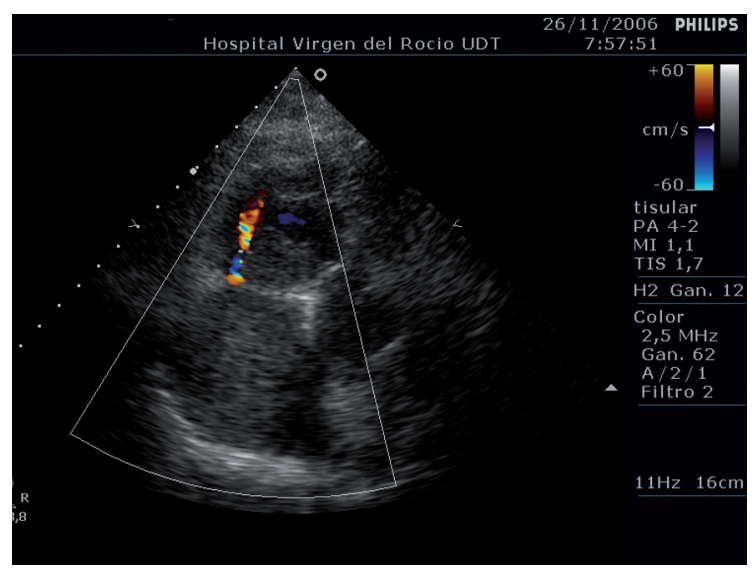

Figura 2.

Mujer de 56 años con antecedentes de hipertensión, diabetes mellitus tipo 2 y fibrilación auricular. Ingresa por tos y disnea progresiva en el último mes. En UCI presenta shock resistente a aminas en altas dosis, acidosis láctica grave y presión venosa elevada, con tonos cardíacos apagados. La ecocardiografía transtorácica muestra gran formación heterogénea mamelonada que ocupa la totalidad de la aurícula derecha (AD) (fig. 1), penetra en el ventrículo y obstruye el paso de sangre, con flujo diastólico transtricuspídeo periférico a la masa, de difícil registro (fig. 2). Tras la resección quirúrgica del tumor adherido a la pared libre y el tabique de la $\mathrm{AD}$, mantiene situación de shock persistente y disfunción múltiple orgánica, con datos bioquímicos de isquemia esplácnica grave; fallece a los 3 días. El informe anatomopatológico final fue de sarcoma pleomórfico indiferenciado.

\section{ANA M. ESCORESCA ORTEGA, FRANCISCO JAVIER ALONSO Y RAFAEL MARTÍN BERMÚDEZ Unidad de Cuidados Intensivos. Servicio de Cuidados Críticos y Urgencias. Hospitales Universitarios Virgen del Rocío. Sevilla. España.}

